\title{
Protective effects of sea cucumber surface-associated bacteria against Vibrio harveyi in brown-marbled grouper fingerlings
}

\author{
Norfarrah Mohamed Alipiah ${ }^{1, *}$, Nur Hasli Syahidda Ramli ${ }^{1}$, Chen-Fei Low ${ }^{1}$, \\ Mariana Nor Shamsudin ${ }^{1,2}$, Fatimah Md. Yusoff ${ }^{1,3}$ \\ ${ }^{1}$ Laboratory of Marine Biotechnology, Institute of Bioscience, Universiti Putra Malaysia, 43400 UPM Serdang, Selangor, \\ Malaysia \\ ${ }^{2}$ Department of Medical Microbiology and Parasitology, Faculty of Medicine and Health Sciences, Universiti Putra Malaysia, \\ 43400 UPM Serdang, Selangor, Malaysia \\ ${ }^{3}$ Department of Aquaculture, Faculty of Agriculture, Universiti Putra Malaysia, 43400 UPM Serdang, Selangor, Malaysia
}

\begin{abstract}
Brown-marbled grouper Epinephelus fuscoguttatus (Forsskål) fingerlings are more vulnerable to diseases than the adult grouper because the fingerlings' adaptive immune system is still in the development stage. The mortality rates are approximately 20 to $70 \%$ during outbreaks of vibriosis in aquacultures of grouper fingerlings. Studies were conducted to identify alternative treatments with low impacts on humans, animals and the environment as well as treatments that minimize the use of antibiotics in aquaculture. In this study, we report the first use of surfaceassociated bacteria isolated from marine invertebrates to increase fingerlings' resistance against infections. Twenty-two surface-associated bacteria were isolated from the sea cucumber Stichopus badionotus and were identified with 16S rRNA gene sequencing. Three of the surfaceassociated bacteria had inhibitory activities against pathogenic Vibrio harveyi and V. parahaemolyticus. The fingerlings treated with the surface-associated bacteria Exiguobacterium acetylicum for $12 \mathrm{~d}$ prior to the challenge experiment with pathogenic $V$. harveyi showed significantly higher survival rates and increases in antibody titres compared to the control group. This study illustrats a symbiotic interaction between E. acetylicum and grouper fingerlings. E. acetylicum colonized the scales of grouper fingerlings and enhanced the fish's immune response against the pathogen $V$. harveyi.
\end{abstract}

KEY WORDS: Epinephelus fuscoguttatus - Surface-associated bacteria - Surface colonizer · Symbiotic relation $\cdot$ Bacterial attachment $\cdot$ Bio-control $\cdot$ Marine bacteria $\cdot$ Immune response

\section{INTRODUCTION}

The brown-marbled grouper Epinephelus fuscoguttatus is an aquaculture commodity with a high market value, and the mariculture industry for this species has expanded tremendously in Southeast Asia due to the increasing market demand. This species reaches a marketable size of $0.5 \mathrm{~kg}$ within 9 to $12 \mathrm{mo}$, and these fast-growing characteristics have made this species a suitable candidate for intensive aquaculture. Groupers are cultured by using floating net cages and are usu-

${ }^{*}$ Corresponding author: norfarrah_80@yahoo.com ally exported as live fish to different countries, including Hong Kong, Japan and Korea. Despite high market demand, farmers are struggling with losses due to the high mortality of fingerlings/fry caused by vibriosis. Pathogens frequently associated with mass mortality during vibriosis outbreaks include Vibrio parahaemolyticus, V. alginolyticus, V. harveyi and V. anguilarrum (Lee 1995). Groupers affected by vibriosis exhibit common clinical signs, including dark skin, pale gills, haemorrhagic areas around the mouth and ulcers on the skin surface (Sarjito et al. 2009).

(C) The authors 2016. Open Access under Creative Commons by Attribution Licence. Use, distribution and reproduction are unrestricted. Authors and original publication must be credited. 
Chemotherapy and vaccination are the current treatments for vibriosis at most aquaculture farms. However, the use of antibiotics and vaccinations are rather difficult, ineffective and environmentally hazardous. Vaccination is time-consuming and impractical for fingerlings. Use of antibiotics has resulted in an increase in pathogen resistance in aquaculture systems, and traces of antibiotics in fish are also hazardous to humans (Defoirdt et al. 2007). In some countries the use of antibiotics in aquaculture is being disputed based on the adverse effects caused; with this argument, antibiotics were completely or partially banned. However, not all countries practice the same laws or enforcement, as there was no standardization in drug residue levels internationally.

Teleost microbiome research has seen significant progress in recent years, yet the marine-derived microbes that produce active compounds against a wide variety of pathogenic bacteria have been largely unexplored. Different strains of culturable marine surface-associated bacteria from sponges, sea urchins, barnacles, tunicates, and seaweeds (Wilson et al. 2010) have been isolated and assayed for antimicrobial ability against target bacterial strains. Further findings on bacterial strains that have been shown to facilitate the development of a vertebrate immune system provide insight into the host-microbial interaction (Rakoff-Nahoum et al. 2004, Kelly et al. 2005, O'Mahony et al. 2008, Hooper et al. 2012). A number of studies have shown that symbiotic interactions between a fish host and its microbiome on the skin and in the gut can be utilized to improve fish health for the prevention or treatment of disease (Spanggaard et al. 2001, Boutin et al. 2012, Llewellyn et al. 2014). Marine surface-associated bacteria have been reported to passively inhibit the colonization of pathogenic bacteria through competitive exclusion and to actively inhibit pathogens by producing toxic secondary metabolites (Wells et al. 1988, Balcázar et al. 2006, Stecher \& Hardt 2008, Llewellyn et al. 2014). Additionally, the host surfaces might also provide optimum growing conditions and nutrient sources for the attached surface-associated microbes. Surfaces provided by the host include biofilms that are rich in organic materials and which contain antifouling agents that discriminate between unwanted attachment and epibiotic bacteria settlement (Armstrong et al. 2001). Surface-associated bacteria that are not pathogenic to the host and which exhibit antagonistic activities against fish pathogens would be the best candidates for bio-control in cultured marine fish. Most previous studies on marine bacterial isolates have involved screening probiotic bacteria for their ability to inhibit pathogenic bacteria in vitro as well as their ability to colonize host surfaces and stimulate of the host immune system. Probiotic bacteria isolated from the microflora of rainbow trout showed inhibitory activity against Vibrio through diffusion assays (Spanggaard et al. 2001). Metabolites secreted by surface-associated microbes contain beneficial compounds that help to protect sea cucumbers against infections. Recent studies on the biodiversity of surface-associated microbial communities suggest that beneficial bioactive compounds, which were previously thought to be host-derived, were shown to be produced by the communities of surface-associated bacteria (Egan et al. 2008).

The relationship between invertebrates and surfaceassociated bacteria varies from sessile to motile invertebrates in terms of maintaining overall health and settlement issues. Invertebrates use compounds secreted by these bacteria as cues to identify appropriate settlement sites where they can benefit from the protective effects of these compounds against other, pathogenic bacteria. Possibilities of gene sharing among those microbes encoded for defence mechanisms have been found amidst the diversity of host-associated microorganisms in coral ecosystems (Krediet et al. 2013). In the motile stage of invertebrates, host-associated microbes that produce biofilms play a role in settlement by providing firmer attachment sites for larvae. Biofilms that attract settling larvae may produce strong stimuli that are sensed by the invertebrates' receptors (Hadfield 2011); however, the actual mechanism of communication between both is still under study. Both Krediet et al. (2013) and Hadfield (2011) showed the importance of microbial communities in an invertebrate's survival, which likely also applies to sea cucumbers. In the present study, we assessed the effects of surface-associated bacteria isolated from the sea cucumber Stichopus badionotus on brownmarbled grouper fingerlings. We hypothesized that surface-associated bacteria improve resistance against Vibrio in grouper fingerlings exposed to pathogenic Vibrio through a symbiotic relationship.

\section{MATERIALS AND METHODS}

\section{Bacteria isolation and phylogenetic affiliations}

Sea cucumbers (Stichopus badionotus) were collected off the west coast of peninsular Malaysia $\left(2^{\circ} 30^{\prime} \mathrm{N}, 101^{\circ} 50^{\prime} \mathrm{E}\right)$ during low tide when the sandrocky habitat area was exposed. The live specimens were then transported to the laboratory in aerated 
seawater tanks. Prior to surface-associated bacterial isolation, the specimens were rinsed 3 times with sterile seawater to remove plankton and loosely attached microorganisms. The specimens were then stirred in $50 \mathrm{ml}$ of sterile seawater using a magnetic stirrer for $5 \mathrm{~min}$ to detach the surface-associated bacteria. A serial dilution of seawater containing epiphytic bacteria was spread on marine agar (Difco) and incubated at $25^{\circ} \mathrm{C}$ for $48 \mathrm{~h}$ (Spanggaard et al. 2001). Individual colonies were selected and streaked on fresh media to obtain pure cultures, which were then stored in $20 \%$ glycerol (MERCK) at $-80^{\circ} \mathrm{C}$.

The phylogenetic affiliation of the surface-associated bacteria was determined by analysing 16S rRNA gene sequences. Genomic DNA was extracted from overnight cultures of the bacterial isolates using the QIAamp DNA mini kit (Qiagen) according to the manufacturer's protocol.

16S rRNA gene was amplified using a forward primer U1 (5'-CCA GCA GCC GCG GTA ATA CG-3') and a reverse primer U2 (5'-ATC GGC TAC CTT GTT ACG ACT TC-3') (Lu et al. 2000). PCR was performed on $100 \mathrm{ng}$ of the extracted genomic DNA in a $25 \mu \mathrm{l}$ reaction of 1 PCR master mix (Bioline) and $12.5 \mathrm{pmol}$ of each forward and reverse primer. The PCR protocol included a pre-denaturation step at $94^{\circ} \mathrm{C}$ for $10 \mathrm{~min}$, followed by 35 cycles of denaturation at $94^{\circ} \mathrm{C}$ for $1 \mathrm{~min}$, annealing at $55^{\circ} \mathrm{C}$ for $1 \mathrm{~min}$, and elongation at $72^{\circ} \mathrm{C}$ for $1 \mathrm{~min}$. There was a final extension step at $72^{\circ} \mathrm{C}$ for $10 \mathrm{~min}$. Amplified 16S rRNA gene fragments approximately at the size $996 \mathrm{bp}$ were purified using the QIAquick Spin PCR purification kit (Qiagen) and sequenced by Solution for Genetics Technologies, South Korea.

PCR amplified 16S rRNA gene sequences of the bacterial isolates were entered into the National Center for Biotechnology Information (NCBI) database (http://blast.ncbi.nlm.nih.gov/Blast.cgi) to perform a sequence homology search (see Table S1 in the Supplement at www.int-res.com/articles/suppl/ q008p147_supp.pdf). The sequences were aligned using the ClustalW function of the alignment editor in MEGA5 freeware (www.megasoftware.net/) and then manually curated. The phylogeny calculations were performed with the Test neighbour-joining tree function with the maximum likelihood approach.

\section{Screening for antagonistic activity}

All strains were tested for inhibitory activity in a well diffusion assay against Vibrio harveyi, V. anguillarum, $V$. alginolyticus and $V$. parahaemolyticus.
Melted marine agar cooled to $45^{\circ} \mathrm{C}$ was inoculated with different species of Vibrio to a final density of $10^{6}$ cells $\mathrm{ml}^{-1}$ agar and poured into Petri dishes (Spanggaard et al. 2001). A total volume of $10 \mu \mathrm{l}$ of the surface-associated bacteria culture $\left(1 \times 10^{8} \mathrm{CFU}\right)$ was added to $5 \mathrm{~mm}$ wells punched in solidified agar plates and incubated at $25^{\circ} \mathrm{C}$. The zone of inhibition around the well was recorded after 24 to $48 \mathrm{~h}$ of incubation.

\section{Bio-control system model and bacterial challenge}

Epinephelus fuscoguttatus fingerlings with body lengths of $\sim 75-100 \mathrm{~mm}$ were acclimated to laboratory conditions for $14 \mathrm{~d}$ and fed daily with commercial pellets. A total of 375 grouper fingerlings were randomly selected and assigned into 5 treatment groups of 25 fingerlings per group. All of the treatments were conducted in 3 replicates. The treatment groups consisted of 2 control groups and 3 treatments with surface-associated bacteria that showed antagonistic activity against different species of Vibrio, including the 3_2W, 3_6O, and 4_3W isolates (see Table 2). The treatments of $10^{12} \mathrm{CFU} \mathrm{ml}^{-1}$ of respective isolates were added daily to the $45 \mathrm{l}$ of seawater in tanks (seawater used was pre-filtered and treated with UV light) containing fingerlings for $12 \mathrm{~d}$ continuously. The seawater in the tanks was changed at a rate of $50 \%$ daily prior to the treatments given. The fish were fed to satiation twice a day with normal feed throughout the treatment period $(5 \%$ body weight $\mathrm{d}^{-1}$ ). Water samples and scale swabs from the fingerlings' dorsal area were collected on Days 1, 6, 12 and 18 for bacterial counts. The water samples and swabs of the fingerlings' scales were processed with serial dilutions before the samples were spread on marine agar and incubated for 24 to $48 \mathrm{~h}$. The number of bacterial colonies growing on the marine agar was recorded for treatment isolates count.

Pathogenic V. harveyi (ATCC 14126) was grown on fish blood agar prior to the challenge experiments (Pasnik et al. 2005). The grouper fingerlings were challenged with pathogenic $V$. harveyi following treatment with surface-associated bacteria on Day 15. The fingerlings received the challenge through an intramuscular injection at the dose of $1 \times 10^{8} \mathrm{CFU}$ in $100 \mu \mathrm{l}$. All treatment groups were challenged with pathogenic $V$. harveyi, except for the control. The unchallenged group served as the negative control. The survival of the fingerlings was recorded and blood samples were collected on Days 0, 1 and 4 post-challenge. The antibody titre in the blood serum was determined by ELISA. The relative percent of 
survival (RPS) was calculated according to the formula proposed by Amend (1981):

$$
\operatorname{RPS}=\left(\frac{1-\% \text { mortality in treatment }}{\% \text { mortality in control }}\right) \times 100
$$

\section{Enzyme-linked immunosorbent assay (ELISA)}

Blood samples of the grouper fingerlings were collected from the caudal vein on Days 0, 1 and 4 post-challenge. The serum was separated from the whole blood by centrifugation at $1000 \times g$ for $20 \mathrm{~min}$. The serum antibody levels were determined with an indirect ELISA. The 96-well ELISA plate was coated overnight with $V$. harveyi $\left(10^{6} \mathrm{CFU} \mathrm{ml^{-1 }}\right)$ dissolved in $100 \mu \mathrm{l}$ per well of coating buffer $\left(15 \mathrm{mmol} \mathrm{l}^{-1}\right.$ $\mathrm{Na}_{2} \mathrm{CO}_{3}, 35 \mathrm{mmol} \mathrm{l}^{-1} \mathrm{NaHCO}_{3}, \mathrm{pH}$ 9.6). The plate was washed 3 times with PBS containing $0.05 \%$ (v/v) Tween-20 then blocked with $250 \mu \mathrm{l}$ per well of $1 \%(\mathrm{w} / \mathrm{v})$ BSA in PBS for $2 \mathrm{~h}$. The plates were washed 3 times with a low salt wash buffer. The serum samples were diluted 1:4 with PBS $(100 \mu \mathrm{l}$ per well), and incubated for $3 \mathrm{~h}$. Then, the samples were washed 3 times with high salt wash buffer. A total volume of $100 \mu \mathrm{l}$ per well of a horseradish- conjugated mouse anti-grouper IgM (1:54) (Aquatic Diagnostic) was added and incubated for $1 \mathrm{~h}$. After washing the samples, a tetramethylbenzidine dihydrochloride $/ \mathrm{H}_{2} \mathrm{O}_{2}$ substrate was added and incubated for $10 \mathrm{~min}$. The reaction was stopped by adding $50 \mu \mathrm{l}$ per well of $2 \mathrm{~mol} \mathrm{l}^{-1} \mathrm{H}_{2} \mathrm{SO}_{4}$. The optical density was measured at $450 \mathrm{~nm}$ with an ELISA reader (Thermo Scientific Multiskan GO). All incubation steps were carried out at room temperature. The results were expressed as the mean \pm SD and were analysed using a 1-way ANOVA. A Tukey HSD test was used for post-ANOVA comparisons.

\section{RESULTS}

\section{Isolation and identification of Stichopus badionotus surface-associated bacteria}

The isolation of surface-associated bacteria from $S$. badionotus resulted in 79 isolates from the agar plates at dilutions of $1 \times 10^{-1}$. The $16 \mathrm{~S}$ rRNA genes of the isolates were sequenced and 22 operational taxonomic units (OTU) that showed $>80 \%$ sequence similarity to strains of bacteria deposited in GenBank were identified from the 3 main bacterial classes:

Table 1. Phylogenetic affiliations of bacteria isolated from the sea cucumber, Stichopus badionotus. The 16S rRNA gene sequences of individual bacterial isolates were compared to the sequences deposited in GenBank. The closest phylogenetic affiliation for each marine isolate is indicated by strain name, accession number, similarity, bacterial group and genus

\begin{tabular}{|c|c|c|c|c|c|}
\hline No. & Isolate & $\begin{array}{l}\text { Closest phylogenetic affiliation } \\
\text { (strain or clone no.) }\end{array}$ & $\begin{array}{l}\text { Accession } \\
\text { no. }\end{array}$ & $\begin{array}{c}\% \\
\text { similarity }\end{array}$ & Bacterial group \\
\hline 1 & 2_1W & Vibrio sp. S4053 & FJ457584 & 99 & Gammaproteobacteria \\
\hline 2 & $2 \_2 \mathrm{O}$ & Uncultured Gammaproteobacterium clone UA07 & DQ269050 & 99 & Gammaproteobacteria \\
\hline 3 & $2 \_2 \mathrm{~W}$ & Uncultured Gammaproteobacterium clone UA07 & DQ269050 & 99 & Gammaproteobacteria \\
\hline 4 & $2 \_2 \mathrm{Y}$ & Uncultured Planococcus sp. clone MUL-10 & EU817575 & 99 & Firmicutes \\
\hline 5 & $3 \_2 \mathrm{~W}$ & Vibrio harveyi NB0901 & HM008702 & 99 & Gammaproteobacteria \\
\hline 6 & 3_3W & Uncultured gamma proteobacterium clone UA07 & DQ269050 & 99 & Gammaproteobacteria \\
\hline 7 & 3_5W & Uncultured gamma proteobacterium clone UA07 & DQ269050 & 99 & Gammaproteobacteria \\
\hline 8 & 3_6O & Exiguobacterium acetylicum QD-3 & FJ970034 & 99 & Firmicutes \\
\hline 9 & $4 \_3 \mathrm{~B}$ & Psychrobacter sp. 19CpB3 & JN602246 & 98 & Gammaproteobacteria \\
\hline 10 & $4 \_30$ & Exiguobacterium profundum & AB752299 & 99 & Firmicutes \\
\hline 11 & $4 \_3 \mathrm{~W}$ & Psychrobacter sp. 19CpB3 & JN602246 & 97 & Gammaproteobacteria \\
\hline 12 & $4 \_50$ & Planococcus sp. D36 & AY582938 & 99 & Firmicutes \\
\hline 13 & $4 \_6 \mathrm{~B}$ & Psychrobacter sp. 19CpB3 & JN602246 & 99 & Gammaproteobacteria \\
\hline 14 & $4 \_60$ & Psychrobacter sp. 19CpB3 & JN602246 & 99 & Gammaproteobacteria \\
\hline 15 & $4 \_6 \mathrm{~W}$ & Psychrobacter sp. 19CpB3 & JN602246 & 99 & Gammaproteobacteria \\
\hline 16 & $4 \_7 \mathrm{~B}$ & Pseudoalteromonas luteoviolacea strain S4060 & FJ457238 & 87 & Gammaproteobacteria \\
\hline 17 & $4 \_7 \mathrm{O}$ & Psychrobacter sp. 19CpB3 & JN602246 & 96 & Gammaproteobacteria \\
\hline 18 & $4 \_7 \mathrm{~W}$ & Psychrobacter sp. 19CpB3 & JN602246 & 96 & Gammaproteobacteria \\
\hline 19 & $4 \_7 \mathrm{Y}$ & Psychrobacter sp. D8 & JX998187 & 91 & Gammaproteobacteria \\
\hline 20 & $4 \_80$ & Planococcus sp. D36 & AY582938 & 99 & Firmicutes \\
\hline 21 & $4 \_8 \mathrm{~W}$ & Sphingomonas echinoides & AB680957 & 99 & Alphaproteobacteria \\
\hline 22 & 4_9W & Vibrio parahaemolyticus CT12 & EU660364 & 99 & Gammaproteobacteria \\
\hline
\end{tabular}


Gammaproteobacteria, Firmicutes, and Alphaproteobacteria (Table 1). Six genera were identified from these 3 main bacterial classes as Vibrio, Planococcus, Exiguobacterium, Psychrobacter, Pseudoalteromonas and Sphingomonas. The Gammaproteobacteria were found to be the dominant class of surface-associated bacteria and consisted of 8 OTUs that were identified as Psychrobacter, 7 OTUs that were identified as Vibrio, including the uncultured Gammaproteobacterium clones, and 1 OTU that was identified as Pseudoalteromonas. The other less dominant surface-associated bacteria had 3 OTUs of Planococcus; 2 OTUs of Exiguobacterium; and 1 OTU of Sphingomonas. Phylogenetic tree analysis revealed the genetic distance between the bacteria based on the 16S rRNA genes sequence. Imported sequence from the GenBank included in this analysis showed different clusters of queries sequences that were less closely related to their nearest representative (Fig. 1).

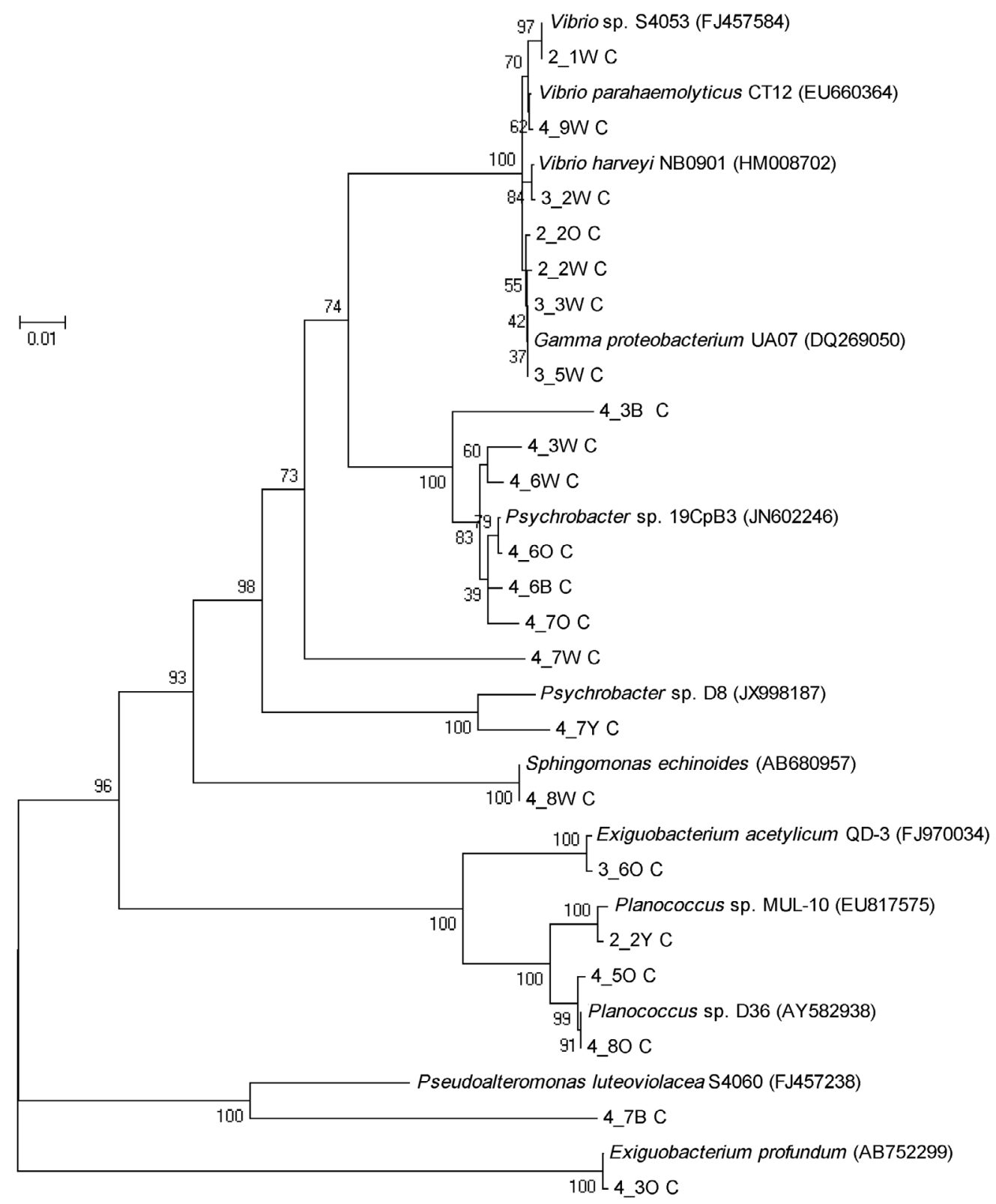

Fig. 1. Phylogenetic tree built with the neighbour-joining method with the aligned 16S rRNA gene sequences of surfaceassociated bacteria isolated from Stichopus badionotus. Sequences from the present study are in code, whereas the close relatives from GenBank are shown with their full name. Maximum parsimony bootstrap values (1000 resamplings) are given for major nodes. The scale bar indicates the number of substitutions per nucleotide position 
Table 2. Antagonistic activity of surface-associated bacteria against different species of Vibrio in a well diffusion assay. Bacterial isolates-3_2W: Vibrio harveyi; 3_6O: Exiguobacterium acetylicum; 4_3W: Psychrobacter sp. Antagonistic activity was assessed by the extension of an inhibition zone: no inhibition (-), $<2 \mathrm{~mm}(+), 2-4 \mathrm{~mm}(++),>4 \mathrm{~mm}(+++)$. Tetracycline treatment $\left(0.5 \mu \mathrm{g} \mathrm{hl}^{-1}\right)$ served as a positive control

\begin{tabular}{lccccc}
\hline Treatment & V. harveyi & $V$. anguillarum & $V$. alginolyticus & $V$. parahaemolyticus \\
\hline 3_2W & + & + & - & ++ \\
3_6O & +++ & +++ & + & ++ \\
4_3W & - & - & - & ++ \\
Tetracycline & +++ & +++ & +++ & +++ \\
\hline
\end{tabular}

\section{Protective effect of surface- associated bacteria}

After $12 \mathrm{~d}$ of treatment with $V$. harveyi (3_2W), E. acetylicum (3_6O), Psychrobacter sp. (4_3W) and 2 untreated controls, all of the treatment groups were challenged with pathogenic $V$. harveyi (except for the unchallenged group that was designated as a negative control). Fingerlings that received treatments with $V$. harveyi (3_2W) and Psychrobacter

\section{Antagonistic effect of surface-associated bacteria}

Out of 22 OTUs, only 3 of the $S$. badionotus surface-associated bacteria isolates showed antagonistic effects against the pathogenic Vibrio spp. that were tested in well diffusion assays (Table 2). The 3 isolates, 3_2W, 3_6O, and 4_3W, were identified as Vibrio harveyi, Exiguobacterium acetylicum, and Psychrobacter sp., respectively. These isolates were used to treat the grouper fingerlings for $12 \mathrm{~d}$, and the attachment of these isolates to the surfaces of the grouper fingerlings were assessed by collecting water samples and scale swabs for bacterial counts (Fig. 2). The surface-associated bacteria isolates did not induce adverse health effects in grouper fingerlings after $12 \mathrm{~d}$ of treatment. There were no symptoms of infection even though a significant increase in the bacterial count was recorded from Day 12 to Day 18 (Fig. 2) in the water and fingerling scale swabs. This outcome indicated that the isolates were not pathogenic and has no adverse effect the grouper fingerlings throughout the treatment periods. sp. (4_3W) suffered $100 \%$ mortality on Day 3 and 4 post-challenge, respectively (Fig. 3). However, both treatments had higher antibody titres on Day 0 and increased titres on Day 1. In contrast, the E. acetylicum (3_6O) treatment resulted in increased protection against pathogenic $V$. harveyi, which was demonstrated by $84 \%$ of RPS as well as the significant ( $p<$ $0.5)$ rise in antibody titres recorded on Day 4 postchallenge (Table 3).

\section{DISCUSSION}

The diversity and antimicrobial activity of surfaceassociated marine bacteria has been previously described using bacteria collected from sponges, sea urchins, barnacles, tunicates, and seaweeds (Wilson et al. 2010). The current study assessed the potential of surface-associated bacteria isolated from Stichopus badionotus as symbiotic microbes to enhance the immune response of Epinephelus fuscoguttatus fingerlings against pathogenic Vibrio harveyi. Llewellyn

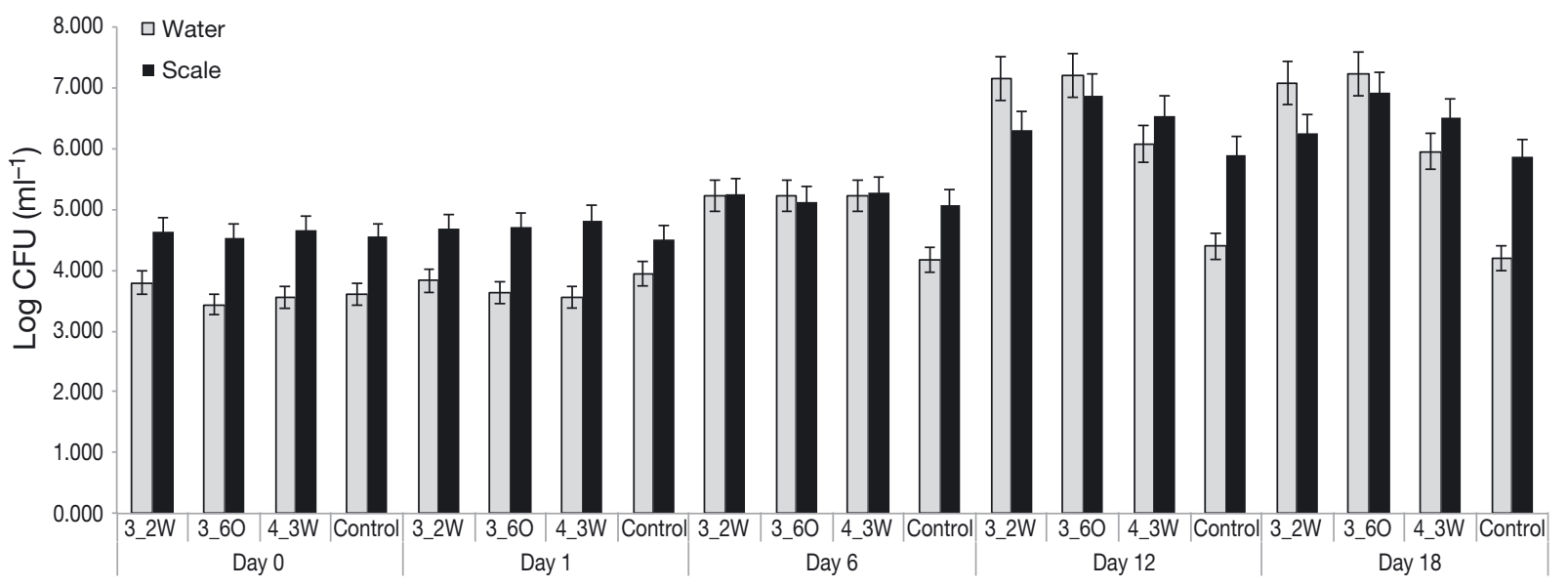

Fig. 2. Amount of bacteria $\left(\mathrm{CFU} \mathrm{m}{ }^{-1}\right.$; mean $\pm \mathrm{SE}$ ) in the water of the experimental tank (grey bars) and scale swabs from the dorsal area (black bars) of brown-marbled grouper fingerlings treated for $12 \mathrm{~d}$ with the surface-associated bacteria Vibrio harveyi (3_2W), Exiguobacterium acetylicum (3_6O), or Psychrobacter sp. (4_3W). The control tank received marine broth 


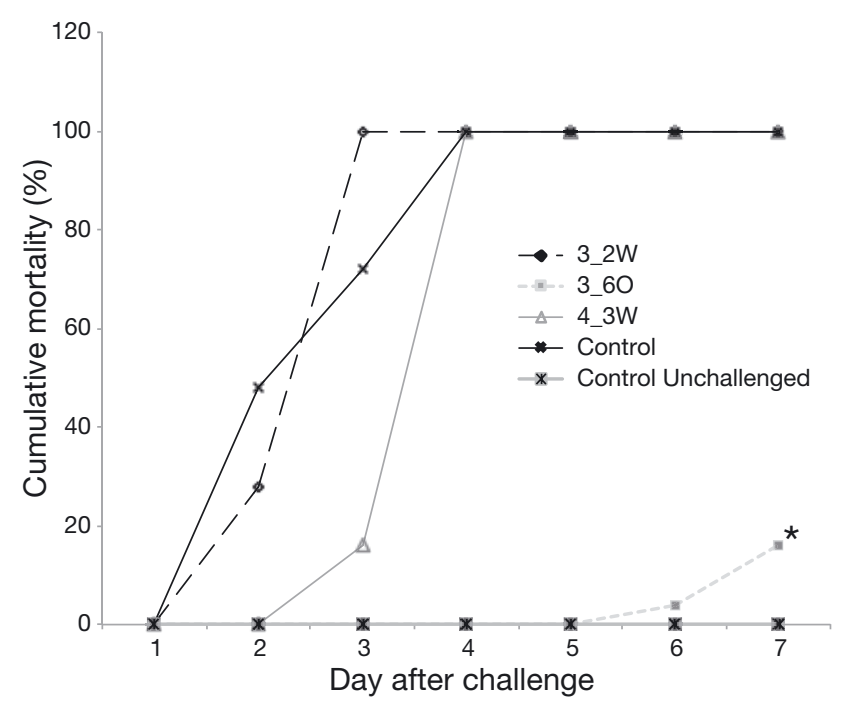

Fig. 3. Effect of surface-associated bacteria on the cumulative mortality of brown-marbled grouper fingerlings challenged with pathogenic Vibrio harveyi. The fingerlings were treated with surface-associated bacteria (Vibrio harveyi, isolate 3_2W; Exiguobacterium acetylicum, isolate 3_6O; or Psychrobacter sp. isolate 4_3W) or marine broth (control) for $12 \mathrm{~d}$ before the challenge ( $\mathrm{n}=25$ for each group). One control group not challenged served as negative control. A star indicates the bacterial cultures that significantly $(p<0.05)$ reduced mortality

et al. (2014) reported that surface-associated bacteria were mostly non-opportunistic pathogens with antigenic properties that would trigger the host immune response and facilitate the development of adaptive immunity. Wilson et al. (2010) reported that most surface-associated bacteria that exhibited antimicrobial activity were closely related, while a few of these were phylogenetically distant. Among the surfaceassociated bacteria isolated from $S$. badionotus, 3 iso-

Table 3. Effect of surface-associated bacteria on anti-Vibrio antibody titres in brown-marbled grouper fingerlings after a challenge with pathogenic $V$. harveyi in a bio-control rearing system. \% mortality count from 25 fingerlings per group in 3 replicates, and relative percent of survival (RPS) calculated as $1-\%$ mortality. Bacterial isolates -3_2W: Vibrio harveyi; 3_6O: Exiguobacterium acetylicum; 4_3W: Psychrobacter sp. -: all fingerlings dead, no measurement possible. Different superscript letters within the same column indicate a significant difference among the treatments according to the Tukey's test $(\mathrm{p}<0.05)$. Control: no pretreatment but challanged; control unchallenged: no pre-treatment, not challenged (negative control). Mean $\pm \mathrm{SE}$

\begin{tabular}{|lccccc|}
\hline Treatment & \multicolumn{3}{c}{ Day } & & \% mortality \\
& 0 & 1 & 4 & & \\
\hline 3_2W & $0.853^{\mathrm{b}} \pm 0.007$ & $0.941^{\mathrm{b}} \pm 0.004$ & - & 100 & 0 \\
3_6O & $0.110^{\mathrm{a}} \pm 0.009$ & $0.147^{\mathrm{a}} \pm 0.002$ & $0.428^{\mathrm{a}} \pm 0.026$ & 16 & 84 \\
4_3W & $0.551^{\mathrm{b}} \pm 0.018$ & $0.953^{\mathrm{b}} \pm 0.022$ & - & 100 & 0 \\
Control & $0.076^{\mathrm{a}} \pm 0.004$ & $0.073^{\mathrm{a}} \pm 0.002$ & - & 100 & 0 \\
Control unch. & $0.066^{\mathrm{a}} \pm 0.001$ & $0.073^{\mathrm{a}} \pm 0.002$ & $0.069^{\mathrm{a}} \pm 0.001$ & 0 & 100 \\
\hline
\end{tabular}

lates from different genera, $V$. harveyi (3_2W), Exiguobacterium acetylicum (3_6O), and Psychrobacter sp. (4_3W) exhibited antagonistic activity against pathogenic Vibrios in a disc diffusion test. The interactions between 2 strains belonging to the same bacterial species, which lead to growth inhibition of the pathogenic strain, may be due to barrier effects (Bergogne-Berezin 1989). The surface-associated bacteria secrete an antagonistic metabolite, a reaction triggered when the pathogenic target bacteria come in contact with the barrier of surface-associated bacteria. All 3 potential probiotic strains found showed different antagonistic ability against Vibrio pathogens, thus isolates in combination might have better synergistic effect against these pathogens. While the combined effects against pathogens were not assayed in this study, a synergistic effect is postulated since the strains were found on the same sea cucumber species that lives in a highly condensed microorganism community and manages to survive.

However, the $V$. harveyi and Psychrobacter sp. that were isolated from the surface of $S$. badionotus showed no protective effect against pathogenic $V$. harveyi in grouper fingerlings compared to the $E$. acetylicum isolate. Nevertheless, grouper fingerlings pre-treated with surface-associated bacteria showed increased (anti-Vibrio) antibody titres, which suggests that the treatment triggered the fingerlings' immune response and potentially protective effects towards other pathogens that were not examined in the current study.

E. acetylicum is normally an extremophile bacterium and has antagonistic properties against a wide range of plant pathogens (Selvakumar et al. 2009). The present study used the isolated strain 3_6O as a treatment, which is phylogenetically related to E. acetylicum from the surface of $S$. badionotus that exhibited antagonistic activity against pathogenic Vibrio species. This isolate is a potential probiotic for microbial control to inhibit opportunistic pathogens in the aquaculture of grouper fingerlings. This finding agrees with those of Selvakumar et al. (2009) and Olafsen (2001). Both studies suggested that bacteria which have antagonistic activities against pathogens and are capable of growing over a wide range of temperatures, such as E. acetylicusm, are excellent probiotic candidates for aquacultures 
(Skjermo \& Vadstein 1999, Olafsen 2001). In our study, E. acetylicum did not induce adverse health effects in the grouper fingerlings after a long exposure period of $12 \mathrm{~d}$.

Exposure of grouper fingerlings to the surfaceassociated bacteria resulted in increased antibody titres, which indicates the uptake of antigens from the skin and gills that subsequently provoked an immune response and the production of antibodies in the grouper fingerlings. These findings are in accordance with similar studies which found that immersion exposure to weakened or manipulated conserved pathogen entities triggers antibody production; an effect that has been shown for rainbow trout, sea bass and other species of fish (Lumsden et al. 1995, Nakanishi \& Ototake 1997, Moore et al. 1998, Dos Santos et al. 2001). Previous related research by our group showed that $S$. badionotus extract has a high ability to inhibit the growth of human pathogens, including the methicillin-resistant Staphylococcus aureus (MRSA) (Alipiah et al. 2015). The same species of sea cucumber from the same location were used in the present study of the effects of surface-associated bacteria on fish immunity. The capabilities of $S$. badionotus against MRSA were believed to be stimulated by the surrounding microbes, and the same mechanism might apply to the fingerlings that received the 3_6O strains that were phylogenetically related to E. acetylicum. Among the 3 surface-associated bacteria isolates, only 3_6O exhibited cross-protective effects against the pathogenic $V$. harveyi challenge in grouper fingerlings. Fish treated with isolates 3_2W and 4_3W exhibited an increase in anti-Vibrio antibody titres, compared to the control, even before challenge with $V$. harveyi, indicating that the treatment had already triggered antibody production against Vibrio antigens. In the treatment with 3_6O, anti-Vibrio antibody titres only increased after challenging with pathogenic $V$. harveyi, showing that the dosage of this isolate did not cause any harm to the fingerlings. In fact, the 3_6O treatments provided sufficient antigenic stimulation along with the specificity to recognize pathogenic $V$. harveyi that they provided a cross-protective effect against this pathogen in grouper fingerlings, as revealed by the rise in the anti-Vibrio antibody titres after challenge along with high RPS. While antibacterial antibodies are produced specifically against bacterial antigens, natural antibodies are produced through various pathways, which makes it difficult to differentiate which process is responsible for the immune response against Vibrio antigens (MatsiotaBernard et al. 1993). In-depth studies need to be done with fingerlings treated by $3 \_60$ or potentially E. acetylicum isolates, investigating the type of antibody production in order to understand how this isolate provides protection.

In conclusion, the present study revealed 3 major aspects of E. acetylicum that makes the bacterium a potent probiotic: (1) E. acetylicum had no adverse health effects on grouper fingerlings following prolonged exposure of up to $12 \mathrm{~d}_{i}(2)$ E. acetylicum was non-opportunistic to the grouper and exhibited antagonistic activity against opportunistic Vibrio species; (3) exposure of the grouper to E. acetylicum sufficiently enhanced the immune response and production of antibodies in the fish for cross-protective effects against pathogenic vibrios. To shed light on the mechanism of action of how 3_6O provides protection on fingerlings, further studies on host immunology and intraspecific barrier effects on bacterial colonization are needed. Understanding the mechanisms of 3_6O protective effects is crucial to increase the survival of brown-marbled grouper fingerlings in a bio-control rearing system after infection, particularly with vibriosis. More information on bacterial colonization factors on the host regulation of the adherent microbiota, and on interactions between the host and the bacteria, is necessary for improving microbial control in an intensive, aquaculture rearing system.

Acknowledgements. This work was supported by research grants from the Universiti Putra Malaysia (Grant no. 0505-10-1075RU), the Malaysia Ministry of Science Technology and Innovation (Grant no. 02-01-04-SF1154) and the Malaysia Ministry of Education Institute of Bioscience at the University Putra Malaysia under the Higher Institution Centre of Excellence program.

\section{LITERATURE CITED}

Alipiah N, Shamsudin M, Yusoff F, Arshad A (2015) Membrane biosynthesis gene disruption in methicillin-resistant Staphylococcus aureus (MRSA) as potential mechanism for reducing antibiotic resistance. Indian J Microbiol 55: $41-49$

Amend DF (1981) Potency testing of fish vaccines. Dev Biol Stand 49:447-454

Armstrong E, Yan L, Boyd K, Wright P, Burgess JG (2001) The symbiotic role of marine microbes on living surfaces. Hydrobiologia 461:37-40

Balcázar JL, de Blas I, Ruiz-Zarzuela I, Cunningham D, Vendrell D, Múzquiz JL (2006) The role of probiotics in aquaculture. Vet Microbiol 114:173-186

Bergogne-Berezin E (1989) Microbial ecology and intestinal infections. Springer, Paris

Boutin S, Bernatchez L, Audet C, Derôme N (2012) Antagonistic effect of indigenous skin bacteria of brook charr 
(Salvelinus fontinalis) against Flavobacterium columnare and F. psychrophilum. Vet Microbiol 155:355-361

> Defoirdt T, Boon N, Sorgeloos P, Verstraete W, Bossier P (2007) Alternatives to antibiotics to control bacterial infections: luminescent vibriosis in aquaculture as an example. Trends Biotechnol 25:472-479

> Dos Santos NMS, Taverne-Thiele JJ, Barnes AC, van Muiswinkel WB, Ellis AE, Rombout JHWM (2001) The gill is a major organ for antibody secreting cell production following direct immersion of sea bass (Dicentrarchus labrax, L.) in a Photobacterium damselae ssp. piscicida bacterin: an ontogenetic study. Fish Shellfish Immunol 11:65-74

Egan S, Thomas T, Kjelleberg S (2008) Unlocking the diversity and biotechnological potential of marine surface associated microbial communities. Curr Opin Microbiol 11:219-225

Hadfield MG (2011) Biofilms and marine invertebrate larvae: what bacteria produce that larvae use to choose settlement sites. Annu Rev Mar Sci 3:453-470

Hooper LV, Littman DR, Macpherson AJ (2012) Interactions between the microbiota and the immune system. Science 336:1268-1273

Kelly D, Conway S, Aminov R (2005) Commensal gut bacteria: mechanisms of immune modulation. Trends Immunol 26:326-333

Krediet CJ, Ritchie KB, Paul VJ, Teplitski M (2013) Coralassociated micro-organisms and their roles in promoting coral health and thwarting diseases. Proc R Soc Lond B Biol Sci 280:20122328

Lee KK (1995) Pathogenesis studies on Vibrio alginolyticus in the grouper, Epinephelus malabaricus, Bloch et Schneider. Microb Pathog 19:39-48

Llewellyn MS, Boutin S, Hoseinifar SH, Derome N (2014) Teleost microbiomes: the state of the art in their characterization, manipulation and importance in aquaculture and fisheries. Frontiers Microbiol 5:207

Lu JJ, Perng CL, Lee SY, Wan CC (2000) Use of PCR with universal primers and restriction endonuclease digestions for detection and identification of common bacterial pathogens in cerebrospinal fluid. J Clin Microbiol 38: 2076-2080

Lumsden JS, Ostland VE, MacPhee DD, Ferguson HW (1995) Production of gill-associated and serum antibody by rainbow trout (Oncorhynchus mykiss) following immersion immunization with acetone-killed Flavobacterium branchiophilum and the relationship to protection from experimental challenge. Fish Shellfish Immunol 5: $151-165$

Editorial responsibility: Megan La Peyre,

Baton Rouge, Louisiana, USA
Matsiota-Bernard P, Mahana W, Avrameas S, Nauciel C (1993) Specific and natural antibody production during Salmonella typhimurium infection in genetically susceptible and resistant mice. Immunology 79:375-380

> Moore JD, Ototake M, Nakanishi T (1998) Particulate antigen uptake during immersion immunisation of fish: the effectiveness of prolonged exposure and the roles of skin and gill. Fish Shellfish Immunol 8:393-407

Nakanishi T, Ototake M (1997) Antigen uptake and immune responses after immersion vaccination. Dev Biol Stand 90:59-68

O'Mahony C, Scully P, O'Mahony D, Murphy S and others (2008) Commensal-induced regulatory $\mathrm{T}$ cells mediate protection against pathogen-stimulated NF- $\mathrm{KB}$ activation. PLoS Pathog 4:e1000112

Olafsen JA (2001) Interactions between fish larvae and bacteria in marine aquaculture. Aquaculture 200:223-247

Pasnik D, Evans J, Klesius P (2005) Nile tilapia, Oreochromis niloticus, blood agar and the culture of fish bacterial pathogens. Bull Eur Assoc Fish Pathol 25:221

Rakoff-Nahoum S, Paglino J, Eslami-Varzaneh F, Edberg S, Medzhitov R (2004) Recognition of commensal microflora by toll-like receptors is required for intestinal homeostasis. Cell 118:229-241

Sarjito, Radjasa OK, Sabdono A, Prayitno SB, Hutabarat S (2009) Phylogenetic diversity of the causative agent of vibriosis associated with groupers fish from Karimunjawa Islands, Indonesia. Curr Res Bacteriol 2:14-21

Selvakumar G, Joshi P, Nazim S, Mishra P, Kundu S, Gupta $\mathrm{H}$ (2009) Exiguobacterium acetylicum strain 1P (MTCC 8707) a novel bacterial antagonist from the North Western Indian Himalayas. World J Microbiol Biotechnol 25: 131-137

Skjermo J, Vadstein O (1999) Techniques for microbial control in the intensive rearing of marine larvae. Aquaculture 177:333-343

Spanggaard B, Huber I, Nielsen J, Sick EB and others (2001) The probiotic potential against vibriosis of the indigenous microflora of rainbow trout. Environ Microbiol 3: 755-765

> Stecher B, Hardt WD (2008) The role of microbiota in infectious disease. Trends Microbiol 16:107-114

> Wells CL, Maddaus MA, Jechorek RP, Simmons RL (1988) Role of intestinal anaerobic bacteria in colonization resistance. Eur J Clin Microbiol Infect Dis 7:107-113

> Wilson GS, Raftos DA, Corrigan SL, Nair SV (2010) Diversity and antimicrobial activities of surface-attached marine bacteria from Sydney Harbour, Australia. Microbiol Res 165:300-311

Submitted: July 27, 2015; Accepted: January 8, 2016

Proofs received from author(s): February 18, 2016 